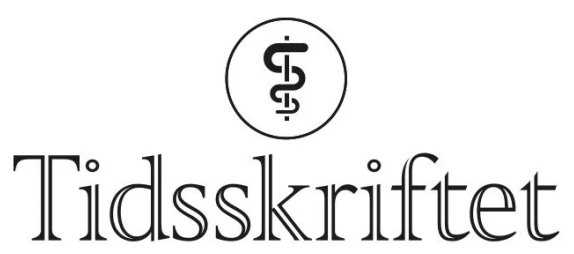

DEN NORSKE LEGEFORENING

\title{
Klarspråk for leger
}

\author{
SPRÅKSPALTEN
}

JOHAN TØNNESSON

j.l.tonnesson@iln.uio.no

Johan Tønnesson er professor i sakprosa ved Institutt for lingvistikk og nordisk studier, Universitetet i Oslo, der han bl.a. leder et bachelorstudium i klarspråk. Artikkelen er en forkortet versjon av hans artikkel «Ti teser om klart språk» i boka Helsespråk.

\section{Leger må uttrykke seg slik at budskapet når frem. Her er 10 utsagn om hva klart språk er og ikke er.}

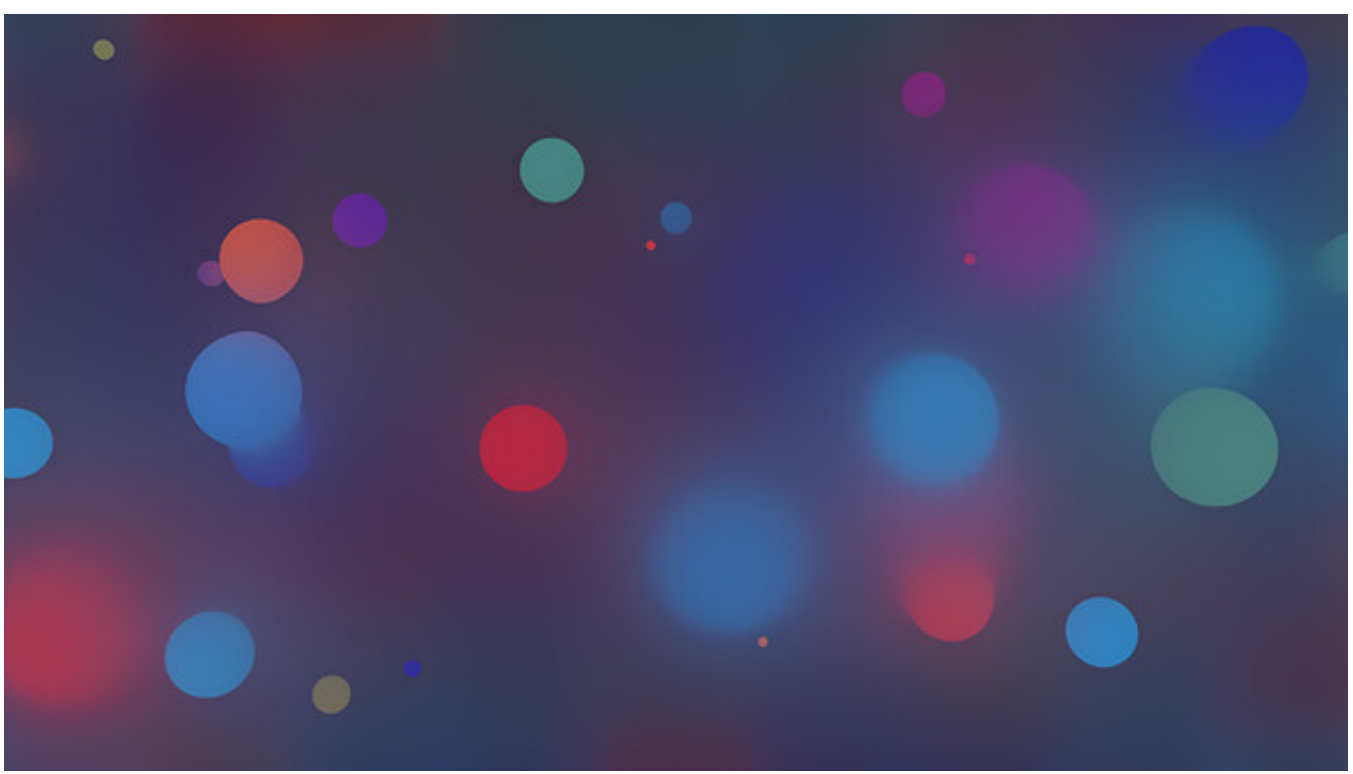

Illustrasjon: Alexey Brin / iStock

Språk er ikke bare språk, men også medisin, sies det gjerne (1ํ). Leger bruker skrift og tale for å kommunisere med pasienter, pårørende, allmennhet, beslutningstakere og hverandre. Da må språket de bruker, være klart og tydelig, slik at budskapet når frem.

Språkrådet definerer begrepet klarspråk som «korrekt, klart og brukertilpasset språk» (므). Jusstudenter får undervisning i klarspråk (3), mens språklig veiledning i medisinstudiet er svært begrenset (4). Her er ti utsagn om klarspråk som kan være til hjelp for å forstå hva klarspråk er (5).

\section{Klart språk er ikke enkelt}


Det er en vanlig misforståelse at alt blir klarere av å bli forenklet. Når vi savner klart språk, er det sjelden at saken er enkel. Selvsagt vil mange tekster bli klarere av å bli forenklet, og det finnes mange eksempler på at enkle budskap kan forklares for komplisert. Gode og forståelige tekster bygger på erfaringer, holdninger og ferdigheter like mye som på språkvettregler.

\section{Intet klart språk uten kontekst}

Det er vanskelig å kommunisere med mange på én gang. En ytring kan være klar for den ene, men uforståelig for andre. Noen ganger kan vi differensiere og kommunisere særskilt for lesere med ulik bakgrunn. Men ofte kommer vi langt med å bygge inn tenkte lesere i teksten.

\section{Klart språk har respekt for faglighet}

Myndighetskommunikasjon er ikke troverdig hvis den ikke er faglig forankret. Svært mye av det myndighetene skal meddele, er gjennomsyret av juss. Derfor må medarbeidere uten juridisk bakgrunn samarbeide med dem som har slik kompetanse. Tilsvarende gjelder for medisin og andre helsefag.

\section{Klart språk er saklig}

Utøvere av klart språk må holde seg til saken og ha en uskreven kontrakt med publikum om at det som ytres er sannferdig. Klarspråk skiller seg fra reklamespråket eller det omdømmebyggende språket, som ikke går av veien for å bygge fiksjoner om produktets egenskaper eller organisasjonens fortreffelighet. Likevel bør ikke klarspråk være knusktørt eller fritt for snert, fantasi og humor.

\section{Klart språk er demokratisk}

Diktatorer kan kommunisere sine ordrer klart og entydig og få innbyggerne til å adlyde, men det er ikke denne klarheten vi tilstreber i et demokrati. I vårt demokratiske samfunn er vi alle brukere av offentlige tjenester og deltakere i demokratiet. Det betyr at klart språk både hjelper oss til å be om velferdsgoder, betale skatt på rett vis og til å gi oss muligheten til å stille oss kritisk til myndighetene og den rådende politikken.

\section{Klart språk er effektivt}

Klart skriftlig språk kan spare en institusjon for tusenvis av tidkrevende telefonsamtaler. Men klart språk bidrar også til å vedlikeholde og styrke tillit. Den pågående koronapandemien har vist at befolkningens tillit til myndighetene fører til en atferd som er gunstig for bekjempelse av pandemien og til å motvirke negative økonomiske konsekvenser.

\section{Klart språk sikrer rettssikkerhet}

Rettssikkerhet innebærer bl.a. at befolkningen er godt informert om sine rettigheter og plikter. Slik informasjon kan være kostbar, slik som når sjukehus skal sende ut brev til flere pasientgrupper med individuelle budskap og hvor retten til å klage på avgjørelser skal 
gjøres reell. Det er da fristende å lage systemer med et minst mulig antall varianter av standardbrev som blir så standardiserte at de knapt passer for noen pasienter.

\section{Klart språk er sammensatt}

Tekster er ofte sammensatt av flere ulike måter å kommunisere på; tenk bare på forskjellen på en overskrift, en ingress og en brødtekst. Med digitaliseringen er det blitt vanligere å legge inn bilder, videosnutter, tabeller, lenker og navigasjonsmuligheter. Vi må beherske mer enn språk.

\section{Klart språk er korrekt}

Det skriftlige verbalspråket er avhengig av en viss normering for å kunne være effektivt og kontaktskapende på samme tid. En tekst full av grammatikalske eller ortografiske normavvik svekker forståelsen hos leseren og leserens tillit til forfatteren.

\section{Klart språk kan være poetisk}

Det finnes en utbredt misforståelse om at kortest mulige setninger med kortest mulige ord fremmer språkets klarhet. Tvert imot er det variasjon som appellerer til oss. Klart språk kan være vakkert.

\section{LITTERATUR}

1. Hem E, Nylenna M. Språk er også medisin. Michael 2021; 18 (supplement 26): 7-13.

2. Språkrådet. Klarspråk - hva og hvorfor? https://www.sprakradet.no/Sprakarbeid/Detoffentlige/Klarsprak/ Lest 12.9.2021.

3. Nordrum JCF. Arbeidet med juridisk klarspråk. Michael 2021; 18 (supplement 26): 201-11.

4. Gjersvik P. Evnen til å uttrykke seg. Tidsskr Nor Legeforen 2021; 141. doi:10.4045/tidsskr.21.0747. [CrossRef]

5. Tønnesson JL. Ti teser om klart språk. Michael 2021; 18 (supplement 26): 212-21.

Publisert: 13. desember 2021. Tidsskr Nor Legeforen. DOI: 10.4045/tidsskr.21.0654

(C) Tidsskrift for Den norske legeforening 2023. Lastet ned fra tidsskriftet.no 26. april 2023. 